http://economix.fr

On the link between current account and oil price fluctuations in diversified economies: The case of Canada 


\title{
On the link between current account and oil price fluctuations in diversified economies: The case of Canada*
}

\author{
Blaise Gnimassoun ${ }^{\dagger}$ Marc Joëts ${ }^{\ddagger} \quad$ Tovonony Razafindrabe ${ }^{\S}$
}

October 17, 2016

\begin{abstract}
This study revisits the important relationship between oil prices and current account for oil exporting countries by paying particular attention to the time-varying nature of this link. To this end, we rely on an innovative method, the time-varying parameter vector autoregressive (TVP-VAR) model with sign restriction. We find that while an oil supply shock has a non-significant impact on the current account, an oil demand shock has a positive and significant effect, which tends to increase over time. In addition, by studying the economic factors underlying the evolution of this relation, we show that the propensity to spend oil revenues on imports has a significant negative influence on the pass-through of oil demand shocks on current account. However, a deepening of the domestic financial market and an accumulation of foreign exchange reserves have a significant positive effect on this relationship.
\end{abstract}

JEL Classification: F32, Q43, C32.

Keywords: Current account, Oil prices, Time-varying parameters.

\footnotetext{
${ }^{*}$ This research has been supported by the French Energy Council (Conseil Français de l'Energie), Paris, France.

${ }^{\dagger}$ BETA-CNRS, University of Lorraine, and EconomiX-CNRS, University of Paris Ouest Nanterre la Défense. E-mail: blaise.gnimassoun@univ-lorraine.fr

${ }^{\ddagger}$ Banque de France, International Macroeconomics Division, and EconomiX-CNRS, University of Paris Ouest, France. E-mail: marc.joets@banque-france.fr

${ }^{\S}$ CREM-CNRS, University of Rennes 1, and EconomiX-CNRS, University of Paris Ouest, France. E-mail: tovonony.razafindrabe@univ-rennes1.fr.
} 


\section{Introduction}

The interaction between macroeconomics and fluctuations in oil prices is one of the most discussed topics in international macroeconomics (see e.g. Hamilton, 1983; Burbidge and Harrison, 1984; Gisser and Goodwin, 1986; Hooker, 1996). The abundance of this literature stems from the key role played by the evolution of oil prices in the formation of external imbalances (deficits for some countries and surpluses for others) and its contribution to economic activity. Thus, the oil price surge in the 2000s was considered partly responsible for worsening and for the persistence of global imbalances ${ }^{1}$ observed during the same period. This view is relayed in the literature by some authors such as Rebucci and Spatafora (2006), Blanchard and Milesi-Ferretti (2010), and Arezki and Hasanov (2013). According to them, oil price dynamics played a leading role in explaining the observed recent global imbalances. Indeed, the sharp and unprecedented increase in crude oil prices from 2003 to 2008 would have resulted in transfers of wealth from oil importers to oil exporters, thereby accelerating these imbalances. Figure 1 illustrates the current account surplus that accompanied the sustained oil price increase for Canada.

Figure 1: Current Account of Canada and Oil Prices

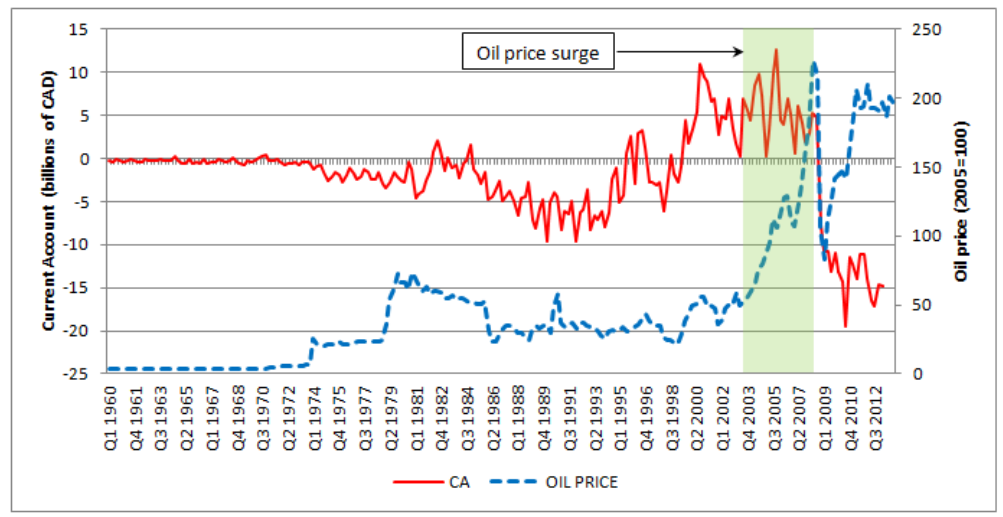

Notes: The series of oil prices are taken from Datastream. They are the average of the U.K. Brent, Dubai, and West Texas Intermediate, end of period prices in USD. Data on the current account are from Macrobond.

Despite the rising interest in the current account - oil price nexus, surprisingly, much fewer

\footnotetext{
${ }^{1}$ The problem of global imbalances is one of the most worrying issue that policy makers and researchers face. To reduce the extent and persistence of these imbalances during the 2000s, the International Monetary Fund (IMF) launched in 2006 the first multilateral consultation on global imbalances. In 2011, the European Union (EU) adopted two regulations on macroeconomic imbalances to detect and correct excessive imbalances. Global imbalances have also been at the centre of discussions at the G20 summits (since 2006) that have given rise to the adoption in 2011 of guidelines for measuring excessive imbalances.
} 
theoretical (Backus and Crucini, 2000, and Bodenstein et al., 2011) and empirical (Bollino, 2007, Kilian et al., 2009, Ozlale and Pekkurnaz, 2010, and Le and Chang, 2013) studies treat directly this issue. ${ }^{2}$ Moreover, no clearcut consensus has emerged, and the common finding from these studies is that the sign and the magnitude of the impact of oil prices on the current account depend crucially on the nature of the economy considered (oil-importing or oilexporting), the degree of domestic financial development, the degree of international financial market integration, and the management of the foreign exchange rate reserves (Buetzer et al., 2012). This point of view is shared by Morsy (2012), who argued that in the context of exhaustible resources, revenue windfalls can be allocated to both savings and investment for intergenerational equity concerns, which thus leaves this important topic as an outstanding issue. The relation between the current account and the price of oil for oil exporting countries also depends on the propensity of the economies to absorb oil shocks (positive or negative), which, in turn, depends on their level of economic diversification. A country with a low level of export diversification and a prominent oil sector will have a current account strongly linked to the oil balance, making systematic the relation between the current account and oil prices.

From this point of view, Canada appears as a particularly interesting case for studying this relation. Indeed, the economic features of Canada differ from those of both oil exporters and oil importers, as pointed out by Kilian et al. (2009). Namely, this country is classified among the largest oil-exporters but its oil exports account for a relatively small share of total exports (less than 20\%), thus indicating a sufficiently diversified export structure. Canada is ranked among the top 10 most diversified countries in the world while being among the top 10 largest oil-exporting countries. This point is interesting for studying the relation between the current account and the price of oil because although this relation is often considered to be linear, especially for countries with little or no diversification, it can be subject to regular disruptions because of the terms of trade in other export sectors (e.g., for Canada, the automotive industry). ${ }^{3},{ }^{4}$

The main objective of this paper is to assess the impact of oil price movements on the current account of Canada taking into account the potential non-linearity of this relation. To this end, we rely on a recent innovative method that permits both disentangling the different sources of oil price fluctuations and assessing the time-varying extent of the relation between current account and oil prices. Namely, we use a time-varying parameters vector autoregressive (TVPVAR) model with sign restriction in line with Primiceri (2005), Cogley and Sargent (2005), and Baumeister and Peersman (2013).

\footnotetext{
${ }^{2}$ Most of the studies have focused on the sustainability of the current account, the reversal of the current account and its economic cost, as well as the role of the exchange rate regime (see among others Edwards, 2005; Freund, 2005; Aizenman and Sun, 2010; Christopoulos and León-Ledesma, 2010; Lane and Milesi-Ferretti, 2012; Schoder et al., 2013).

${ }^{3}$ When the oil balance is predominant in the current account (the case of essentially oil countries), any change in oil prices is likely to mechanically drive the current account in the same direction.

${ }^{4}$ Section 2 returns more broadly to the reasons that make Canada's case unique and interesting to study.
} 
Despite the country-case nature of this study, our paper contributes to the literature in several ways. First, we offer a recent and updated comprehensive literature review of studies that treat, directly or indirectly, the nexus between current account and oil prices. Second, it accounts for the fact that 'not all oil price shocks are alike' (Kilian, 2009) by distinguishing the effects of oil prices due to a supply shock, and those derived from a demand shock. That is, oil price shocks may stem from different sources, such as an oil supply disruption or an unexpected change in oil demand. ${ }^{5}$ Indeed, an oil price increase due to an oil production shortfall would not have the same impact on the current account as an unexpected increase in the demand for oil. A rise in oil prices associated with a production shortfall might compensate for the resulting loss in revenue, whereas that associated with a rise in demand triggers an oil revenue windfall. In this vein, this paper assesses the link between current account and oil price fluctuations by disentangling the different sources of oil price fluctuations, namely those that come from oil supply disruption and those that follow an unexpected rise in precautionary or physical oil demand. Third, allowing the relation between the current account and the price of oil to be time-varying, we leave the beaten track, where a linear relation is often assumed, while some authors, such as Le and Chang (2013), argue the opposite. By dividing the sample of their studies into three different episodes, those authors show that the relation between the current account and oil prices varies considerably from year to year in terms of magnitude, sign, and signal of causality. The main obvious rationale for this finding is that different sources of oil price fluctuations do not necessarily occur at the same time. Therefore, the time-varying nature of oil price shocks leads to an unstable relation between oil prices and macro-economic variables, as argued by Kilian (2009) and Kilian et al. (2009). Moreover, Baumeister and Peersman (2013) argue that changes in factors such as the oil intensity of economic activity, energy market regulations, the capacity utilization rate in crude oil production, and the degree of oil market financialization, are probable drivers of the timevarying nature of the relation. Therefore, we propose to estimate for the whole sample period considered in this study the extent of the oil-price elasticity of current account. Furthermore, our paper provides some explanations for the relation between the current account and oil price fluctuations for Canada, which has not often been the case in previous studies.

As is standard in the literature, we find a positive relation between oil prices and current account, indicating that an oil price increase is followed by a current account surplus for oil exporting countries. Moreover, an impulse response analysis shows that an unexpected oil price increase following an unexpected oil production shortfall does not have a significant impact on the current account. In constrast, oil demand shocks have a significant positive effect on the latter. More interestingly, the time-varying specification that we adopt in this study allows us to obtain two main results. First, we find that the oil price and current account nexus has increased over time and is mainly demand driven. Second, by conducting a

\footnotetext{
${ }^{5}$ Given the increasing financialization of oil markets and the prominent role played by speculators, Kilian and Murphy (2014) made a distinction between physical demand and speculative shocks in explaining oil price fluctuations.
} 
formal assessment of the influence of adjustment factors on the oil price and current account nexus, we find that the positive impact of an oil price increase on the current account is mitigated by the propensity to spend an oil revenue windfall on imports. In constrast, the degree of domestic financial development and the accumulation of exchange rate reserves have a significant positive impact on the link between oil prices and current account.

The rest of this paper is organized as follows: Section 2 provides a review of the recent literature; Section 3 presents the empirical method used; Section 4 discusses the results; and Section 5 concludes.

\section{Oil shocks and external balances}

\subsection{A global perspective}

A large body of literature has investigated the relation between oil prices and macroeconomics in oil-importing countries by looking either at (i) the effect of an oil price shock on economic activity through the supply and demand channel ${ }^{6}$, or at (ii) the impact of the global economy on oil price movements. ${ }^{7}$ However, little has been done to investigate the impact of oil price shocks on external balances in oil-importing and oil-exporting countries, whereas recent discussions have suggested that oil prices have played a prominent role in determining global imbalances (see Rebucci and Spatafora 2006; Blanchard and Milesi-Ferretti 2010; and Arezki and Hasanov 2013).

A rather important literature has indirectly studied this question through the so-called 'Dutch disease' phenomenon. ${ }^{8},{ }^{9}$ One can cite, among other papers, Corden and Neary (1982), Chen and Rogoff (2003), Cashin et al. (2004), Chen and Chen (2007), Coudert et al. (2011), and more recently Bodart et al. (2012, 2015), who suggest that there exists a positive long-run

\footnotetext{
${ }^{6}$ The supply channel refers to terms-of-trade shocks following an exogeneous increase of the price of imported crude oil, where crude oil is considered as an intermediate input influencing the domestic economy through its effects on production decisions (see, among others, Kim and Loungani 1992; Backus and Crucini 2000). This approach has been confronted with the demand channel, where the effect of oil price shocks can be seen as the reduction in the demand for goods and services (see, among others, Lee and Ni 2002; Bernanke 2006; Kilian 2008b; and Hamilton 2009).

${ }^{7}$ See Barsky and Kilian (2002), Kilian (2009), Alquist and Kilian (2010), Kilian and Vega (2011), and Kilian and Murphy (2014), to name a few.

${ }^{8}$ The indirect implication of this strand of the literature on the nexus between oil prices and external balances comes from the existing relation between the real exchange rate, the current account, and the commodity price dynamics.

${ }^{9}$ The 'Dutch disease' literature belongs to the more general 'Natural Resource Curse' literature, which stresses that increases in commodity prices have negative effects on the economic growth of commodity producing countries. See Frankel (2010) for a recent survey of this topic.
} 
relation between the price of oil (commodity prices in general) and the real exchange rate via the terms of trade. According to this literature, depending on various factors (such as the exchange rate regime, the degree of financial openness, the degree of trade openness, the degree of export diversification, the degree of institutional constraints, etc.) an oil price increase will lead to a real exchange rate appreciation for oil-exporting countries. In turn, this real exchange rate appreciation will generate a deterioration in the terms of trade for non-oil exporting firms ('income effect') and a resource transfert from non-oil to oil sectors ('substitution effect'). ${ }^{10}$ Another indirect literature is to link the current account to the net savings (savings minus investment) in an accounting identity in order to understand the impact of the domestic oil investment-savings allocation on external balances. ${ }^{11}$

More directly related to our context, Bruno and Sachs (1982), Gavin (1990, 1992), and Ostry and Reinhart (1992) were among the first to study the direct impact of oil price shocks on external accounts. However, these studies appear to be limited by not considering the endogeneous and exogeneous components of oil price shocks, whereas recent theoretical and empirical models suggest that not all oil shocks are alike (see Barsky and Kilian 2002, 2004; Kilian 2008; Kilian 2009; Alquist and Kilian 2010; Kilian and Murphy 2014, to name a few). ${ }^{12}$ More recent studies by Kilian et al. (2009) and Bodenstein et al. (2011) investigate how oil revenues are recycled in the global economy by distinguishing betwen supply and demand shocks. A common finding from these studies is that an oil price increase will result in a positive external balance for oil exporters at the expense of oil importers. An in-depth examination of the effect of an oil price shock on external accounts reveals that two channels are usually at work: (i) the trade channel, and (ii) the valuation channel. While the former channel works through the adjustment of the prices and quantities of exported and imported goods, reflecting the response of trade accounts ${ }^{13}$ (see Kilian et al. 2009; and Bodenstein et al. 2011), the latter works through the adjustment of income flows and foreign liability positions reflecting the international portfolio structure of oil-importing and oil-exporting countries. Focusing on the macroeconomic ajustments of the current account, we leave aside the mechanisms related to the role of the valuation effects in the external adjustment of economies. $^{14}$

\footnotetext{
${ }^{10}$ See Neary (1988) for more details.

${ }^{11}$ See Bems and Carvalho (2011) and Cherif and Hasanov (2013) for the savings behavior of oil-exporting countries; Chinn and Ito (2007), Van der Ploeg and Venables (2012), Basher and Fachin (2013), and Allegret et al. (2013) for the role of domestic investment.

${ }^{12}$ The implicit reasoning behind the standard pre-1990 models was that (i) oil prices are treated as exogeneous with respect to the global economy; and (ii) the effect of an exogeneous oil price shock will be the same regardless of its origin (i.e., demand or supply shocks).

${ }^{13}$ As in Kilian et al. (2009), the trade balance here is equivalent to the merchandise trade balance, composed of the oil-trade and non-oil trade balances. In turn, we assume that the response of the current account following an oil price shock is mainly reflected in the merchandise trade balance.

${ }^{14}$ The interested reader can refer to Lane and Milesi-Ferreti (2007a), Gourinchas and Rey (2007a,b), Devereux and Sutherland (2010) and Ghironi et al. (2015), among others.
} 
From a macroeconomic perspective, it follows that after a positive oil price shock, oil-exporting (respectively, oil-importing) countries adjust their trade accounts by running an oil-trade balance surplus (respectively, deficit). Recalling that the trade balance is composed of the oil-trade and non-oil trade balances, and that it largely determines the evolution of the current account, it remains that the adjustments of the latter depend to a large extent on the reaction of the non-oil trade balance with respect to the oil-trade one. According to the literature, the role of the non-oil trade balance is indeed of primary importance, since it can either amplify the initial effect (especially for countries that export non-oil forms of commodities which could be affected by oil disturbances ${ }^{15}$ ), or offset the oil trade deficits (Kilian et al., 2009; Buetzer et al.; 2012). As pointed out by Kilian et al. (2009), the response of the nonoil trade balance also sheds much light on the international financial market integration as well as on the management of foreign exchange reserves. From the viewpoint of international financial integration, it is well known that the adjustment of external balances adjustment differs, depending on the completeness of the markets. Indeed, there are usually found in the literature three possible situations vis-à-vis the international financial markets: (i) complete markets, (ii) financial autarky, and (iii) incomplete markets. Under the standard framework of complete markets, a positive temporary oil price shock led the oil-exporting countries to lend their surplus of oil revenues. For oil importing countries, the oil deficit must be financed by borrowing in order to maintain a sustainable current account imbalance (a transitory flow imbalance). It follows that no internal adjustment will be required and the current account will react only to the oil-trade balance. ${ }^{16}$ Under the extreme framework of financial autarky, by definition, external current account imbalances cannot emerge in response to oil price shocks. Standard theoretical models focus on the complete or autarky cases only, and little is known about the incomplete situation. Nevertheless, this last case appears to be the more realistic one. Thus, under the assumption of incomplete markets, adjustments of the non-oil trade balance are required to cushion the oil-trade balance movements. Such an adjustment works through a change in the terms of trade via a real exchange rate appreciation or depreciation (see Cashin et al. 2004; Chen and Chen 2007; and Kilian et al. 2009). Looking now to the role of foreign exchange reserves as an adjustment factor, Buetzer et al. (2012) show that while the exchange rates of oil exporters do not systematically appreciate with respect to those of oil importers after shocks raising the real price of oil, oil exporters experience significant appreciation pressures following an oil demand shock: to counter this, countries accumulate foreign exchange reserves. ${ }^{17},{ }^{18}$ It follows that the non-oil trade balance is not affected by the oil price shock and that the overall effect on the trade balance is captured in the oil-trade balance alone.

\footnotetext{
${ }^{15}$ See Baumeister et al. (2010).

${ }^{16}$ If the shock is permanent, it should lead to a full internal adjustment. However, because such an adjustment is costly, external imbalances may arise even in the case of a permanent oil price increase.

${ }^{17}$ This result also confirms that not all oil shocks are alike when investigating the effect on macroeconomic aggregates.

${ }^{18}$ The adjustment process works broadly in the opposite way for oil-importing countries.
} 


\subsection{Oil shocks and current account in diversified countries: The case of Canada}

As discussed in the previous section, a small body of literature has studied the impact of oil price shocks on external accounts. More specific country case studies are concerned with oil-importing countries, such as Bollino (2007) for United States and Ozlale and Pekkurnaz (2010) for Turkey, where both find a significant effect of oil price shocks in the short run. ${ }^{19}$ Others focus on the Asian emerging oil-importing and -exporting countries, such as Le and Chang (2013) for Malaysia, Singapore and Japan. A more general study is Kilian et al. (2009), who investigate the effect of oil shocks on external balances by considering a large panel of oil-importing and exporting countries. However, the countries considered in the literature are pretty much the same in terms of trade balance structure and export diversification, while nothing is known about well diversified exporting countries such as Canada. As pointed out by Kilian et al. (2009), Canada is likely to behave differently from both oil-importing advanced economies and from major oil exporters. Four reasons can justify a specific interest in focusing on the behaviour of this country when looking at the oil shocks-current account nexus.

First, Canada is the only advanced economy among the top 10 oil-exporters in 2013, with 1,643 thousand barrels per day. Furthermore, it is also one of the main oil consumers in 2013, with 2,431 thousand barrels per day against 4,074 thousand barrels per day produced, conferring a leading role to the country within the world oil market organization. Second, while the configuration of the main oil-exporting countries has been quite stable from the 1980s, Canada switched from being a net oil-importer (up to 1982) to a net oil-exporter. Third, according to the U.S. Energy Information Administration and the Oil \& Gas Journal, Canada controls the third-largest amount of proved reserves in the world in 2014, with 173 billion barrels, after Venezuela and Saudi Arabia (297 and 268 billion barrels, respectively). ${ }^{20}$ This situation therefore gives to the Canadian economy an important role in the future framework of the world oil market. Fourth, looking more specifically at the structure of the exports for 19952013 (Table ??), it appears that while Canadian exports are large in absolute value, the fuel share is less than $20 \%$ compared to $81 \%$ on average for OPEC member countries testifying to the well diversified struture of the Canadian trade balance. ${ }^{21}$ Figure 1, which reports the export diversification Theil index of the considered countries following the definitions and methods used in Cadot et al. (2011), confirms this observation for 1982-2010, where

\footnotetext{
${ }^{19}$ Note that Bollino (2007) sets forth an alternative explanation of the effect of oil prices on the U.S. trade deficit, taking in account the 'twin nature' of the overall trade definition, namely (i) the petroleum trade deficit, and (ii) the China bilateral trade deficit.

${ }^{20}$ The dynamics of the Canadian crude oil proved reserves has considerably changed over time: from 1980 to 2002 they were well below 10 billion barrels. In 2003, they rose to 180 billion barrels after oil sand resources were deemed to be technically and economically recoverable.

${ }^{21}$ Considered oil-exporting countries in Table ?? are those of Kilian et al. (2009), where we add Canada and the UK.
} 
Canada appears to be one of the most diversified countries. ${ }^{22}$ Looking more specifically at the stucture of the fuel exports, Table 1 also reveals that Canada also exports non-oil energy (such as gas, coal and electricity) but that the share of non-oil energy is low (around $7 \%$ of the total). ${ }^{23}$ The remainder of the total exports is in the form of exported manufactured goods $(54 \%)$ and others (26\%). Another particularity of Canada's crude oil exports is that they are profoundly dependent on the United States: in 2013, 97\% of Canada's oil exports went to the U.S., constituting one-third of the U.S.'s crude oil imports. ${ }^{24}$ Overall, Canada appears to be specific compared to the behaviour of both oil-exporting and -importing countries, a paradox that the literature has previously ignored even though this case is of primary interest.

Another interesting comparison that shows the specificity of Canada is with the UK. Indeed, a first examination reveals that, as with Canada, the UK is also quite different from the other main oil-exporting countries, especially in the structure of its export diversification (see Table ?? and Figure 1). Based on this basic evaluation, one could say that both the UK and Canada are approximately the same and can be classified within the same subgroup of exporters. However, this observation is not supported by the data. Indeed, fundamental differences exist between the two exporters. First, looking at the net crude oil positions of the two countries (i.e. the difference between crude oil exports and imports) over the period 1980-2013 ${ }^{25}$ (Figure 3) reveals that while both countries switched from being a net-importer to a net-exporter over time, in the beginning of the 2000s the divergence between the two series has increased to the point that the UK has become a net importer of crude oil since 2003, making it a net importer of all fossil fuels for the first time since at least the early 1970s. Second, unlike Canadian crude oil proved reserves, which have continuously increased since the early 2000s, the UK crude oil proved reserves started to decline from the beginning of the 1980s. Last but not least, while the UK is a net importer of non-oil energy, Canada is a net exporter of both oil and non-oil energy. Thus, a thorough analysis of the data confirms the importance of distinguishing Canada from the other main oil-exporters, especially when looking at the effect of oil prices on the external balance.

\footnotetext{
${ }^{22}$ The codes used for the countries displayed in Figure 1 are the following: Algeria: DZA; Angola: AGO; Azerbaijan: AZE; Canada: CAN; Congo: COG; Ecuador: ECU; Gabon: GAB; Indonesia: IDN; Iran: IRN; Kazakhstan: KAZ; Kuwait: KWT; Libya: LBY; Mexico: MEX; Nigeria: NGA; Norway: NOR; Oman: OMN; Qatar: QAT; Russia: RUS; Saudi Arabia: SAU; Syria: SYR. Trinidad and Tobago: TTO; Turkmenistan: TKM; United Arab Emirates: ARE; Venezuela: VEN and Yemen: YEM.

${ }^{23}$ More precisely, Canada ranks as the fourth-largest exporter of natural gas, behind Russia, Qatar, and Norway. It exports more than $50 \%$ of the coal produced, and is a net exporter of electricity.

${ }^{24}$ While overall U.S. crude oil imports are declining, crude oil imports from Canada are increasing. To stress the close trade relations between the two countries, Canada is also the only country to import U.S. crude oil $(133,000 \mathrm{bb} / \mathrm{d}$ in 2013).

${ }^{25}$ Data are from the U.S. Energy Information Administration.
} 
Table 1: Exports of the main oil-exporting countries (percent of total exports)

\begin{tabular}{|c|c|c|c|c|c|c|c|}
\hline \multirow[t]{2}{*}{ Country } & \multicolumn{5}{|c|}{ Fuels } & \multirow[t]{2}{*}{ Manufact. goods } & \multirow[t]{2}{*}{ Others } \\
\hline & Petroleum & Gas & Coal & Electricity & Total & & \\
\hline Algeria & 60.61 & 37.13 & 0.00 & 0.01 & 97.75 & 1.17 & 1.08 \\
\hline Angola & 96.61 & 0.61 & 0.00 & 0.00 & 97.22 & 0.37 & 2.41 \\
\hline Azerbaidjan & 1.35 & 2.08 & 0.04 & 0.72 & 4.20 & 77.02 & 18.79 \\
\hline Bahrain & 14.47 & 0.04 & 0.06 & 0.00 & 14.57 & 63.82 & 21.61 \\
\hline Brunei & 2.35 & 0.07 & 0.02 & 0.00 & 2.44 & 77.97 & 19.59 \\
\hline Canada & 12.38 & 5.25 & 1.03 & 0.59 & 19.25 & 54.45 & 26.31 \\
\hline Congo & 3.98 & 0.06 & 0.02 & 0.46 & 4.06 & 76.78 & 19.15 \\
\hline Ecuador & 14.04 & 3.10 & 0.02 & 0.46 & 17.63 & 70.82 & 11.55 \\
\hline Gabon & 3.59 & 0.22 & 0.07 & 0.00 & 3.88 & 76.13 & 19.99 \\
\hline Indonesia & 10.42 & 9.79 & 8.34 & 0.00 & 28.55 & 42.25 & 29.21 \\
\hline Iran & 74.46 & 2.51 & 0.03 & 0.04 & 77.05 & 11.33 & 11.62 \\
\hline Iraq & 98.07 & 0.06 & 0.00 & 0.00 & 98.13 & 0.72 & 1.15 \\
\hline Kazakhstan & 63.22 & 3.24 & 1.52 & 0.09 & 68.07 & 13.11 & 18.82 \\
\hline Kuwait & 85.42 & 4.91 & 0.01 & 0.00 & 90.33 & 7.96 & 1.70 \\
\hline Libya & 90.88 & 4.77 & 0.00 & 0.00 & 95.65 & 3.42 & 0.92 \\
\hline Mexico & 12.86 & 0.05 & 0.00 & 0.07 & 12.98 & 76.64 & 10.37 \\
\hline Nigeria & 86.83 & 7.61 & 0.00 & 0.03 & 94.47 & 1.78 & 3.75 \\
\hline Norway & 43.28 & 20.27 & 0.00 & 0.45 & 63.99 & 18.84 & 17.17 \\
\hline Oman & 64.34 & 12.26 & 0.00 & 0.00 & 76.61 & 12.30 & 11.09 \\
\hline Qatar & 46.69 & 41.04 & 0.00 & 0.00 & 87.73 & 7.44 & 4.83 \\
\hline Russia & 46.25 & 13.93 & 1.98 & 0.23 & 62.61 & 17.16 & 20.43 \\
\hline Syria & 10.39 & 1.45 & 0.03 & 0.17 & 12.04 & 62.95 & 25.01 \\
\hline Saudi Arabia & 82.08 & 3.02 & 0.01 & 0.00 & 85.10 & 12.76 & 2.14 \\
\hline Trinidad \& Tobago & 29.06 & 0.03 & 0.05 & 0.00 & 29.14 & 54.96 & 15.90 \\
\hline Turmenistan & 1.16 & 0.03 & 0.05 & 0.00 & 1.20 & 85.02 & 13.77 \\
\hline UAE & 53.73 & 5.13 & 0.03 & 0.00 & 58.89 & 23.02 & 18.10 \\
\hline UK & 8.78 & 0.87 & 0.05 & 0.04 & 9.73 & 70.50 & 19.77 \\
\hline Venezuela & 81.53 & 0.50 & 0.73 & 0.03 & 82.79 & 11.85 & 5.37 \\
\hline Yemen & 19.24 & 0.03 & 0.07 & 0.00 & 19.34 & 46.75 & 33.91 \\
\hline
\end{tabular}

Notes: Data from UNCTAD's database on the structure of trade by product. 
Figure 2: Exports diversification index for main oil-exporting countries (1982-2010)

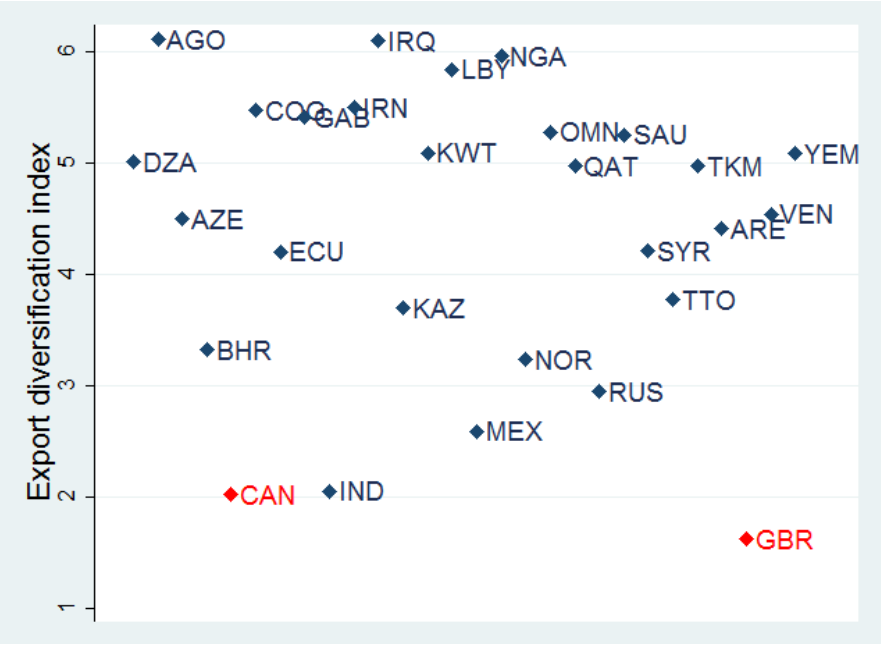

Notes: Average Theil export diversification index 1982-2010 from the International Monetary Fund (based on an updated version of the UNNBER dataset). A lower index indicates that the economy is more diversified.

Figure 3: Crude oil trade balance of the UK and Canada

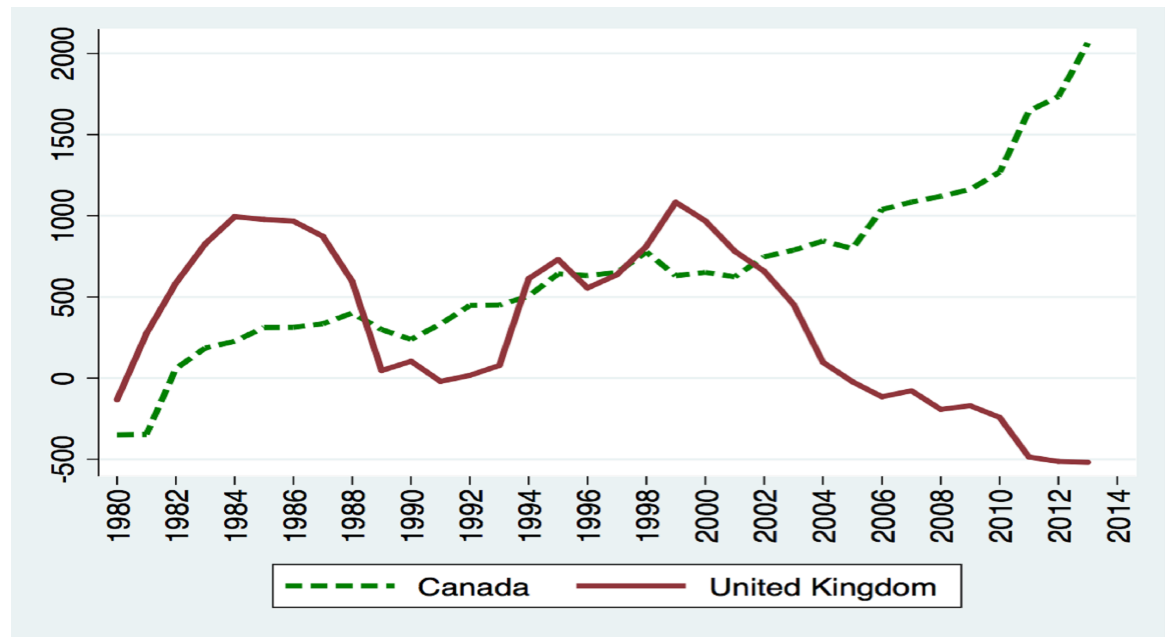

Notes: Crude oil (including lease condensate) trade position of the UK and Canada (i.e. the difference between crude oil exports and imports) 1980-2013 in thousands of barrels per day. 


\section{Empirical Methodology}

This section describes briefly the dataset and the empirical method. More specifically, it justifies the theoretical and empirical reasoning of our time-varying framework with sign restrictions.

\subsection{Data}

The North American crude oil market framework has changed profoundly over time, especially during recent years with the development of unconventional oil production, in particular 'tight' oil from oil-bearing shale formations. ${ }^{26},{ }^{27}$ Coupled with this rapid expansion of North American crude oil production from unconventional sources, an accumulation of an oil surplus in the U.S. Midwest has lead to a segmentation of the North American crude oil market from the global market. ${ }^{28}$ This segmentation has contributed to the increasing divergence between the continental benchmark (such as the West Texas Intermediate (WTI)) with the seaborne benchmark (such as the Brent). In order to account for such a divergence in the impact of oil shocks on the current account in Canada, we use the WD commodity price index, which is the nominal price of oil computed as the average of the Brent, Dubai Fateh, and WTI prices. We then deflated this index by the U.S. consumer price index in order to obtain the real price of oil. The data about the global oil market or macroeconomic aggregates are described in Appendix A.

\subsection{Disentangling shocks in the price of oil}

One important issue when investigating the impact of oil price shocks on current account is to understand the intrinsic nature of the oil price fluctuations. As seen in section 2, previous studies (except Kilian et al. 2009) have treated oil shocks as the same regardless of the origin of the fluctuations. Yet this seemingly minor question is of primary importance in the literature, since it opposes the view in favour of the exogeneity of oil against the one of endogeneity. In this debate, it is now widely accepted that oil prices are not only determined by supply-side factors but also driven by demand conditions (i.e. oil prices are

\footnotetext{
${ }^{26}$ Three factors have enabled the development of the shale oil revolution, specifically in the U.S.: a history of shale gas exploitation, a legally and institutionally attractive environment, and an advanced oil production infrastructure (see Alquist and Guénette 2014).

${ }^{27}$ The shale oil revolution was also made possible by the relatively high level of crude oil prices during the past decade. Indeed, a precondition for the commercial viability of the extraction of tight oil is a price level above about $\$ 50$ per barrel.

${ }^{28}$ According to Alquist and Guénette (2014), logistical constraints, legal restrictions on export, and the shipping of domestically produced crude oil have segmented the North American market from the global one.
} 
mainly endogenous with respect to macroeconomic activity). Indeed, the empirical literature has provided overwhelming evidence that oil prices (and commodity prices in general) have been driven by global macroeconomic activity (see Barksy and Kilian 2002, 2004; Kilian 2008; Hamilton 2009; Kilian 2009; Alquist et al. 2013; Kilian and Murphy 2014). ${ }^{29}$ More importantly, it appears that the effects of demand and supply shocks in the crude oil market on macroeconomic aggregates are different, depending on whether the oil price increase is driven by demand from global economic activity, disruption in global production, or an oil-specific demand shock (the so-called speculative demand shock). ${ }^{30}$

Therefore, as is common in the literature, four types of shocks can be distinguished when looking at the effect of oil prices on current account: (i) shocks to the flow supply, (ii) shocks to the flow demand for crude oil reflecting the state of the global business cycle, (iii) shocks to the speculative demand for oil stocks above the ground (oil specific demand shocks), and (iv) other idiosyncratic oil demand shocks. ${ }^{31}$ The economic significance of the supply and demand components on current account is quantified in the structural model developed in Section 3.3.

\subsection{The time-varying nature: A TVP-VAR model}

There is considerable evidence in the empirical and theoretical literature that the relation between oil prices and macroeconomic activity (especially in the U.S.) has been unstable over time (see, among others, Edelstein and Kilian 2009; Herrera and Pesavento 2009; Blanchard and Galí 2010; Ramey and Vine 2011; Baumeister and Peersman 2013). ${ }^{32}$ According to the literature, such time-varying effects may have different features, such as an improved monetary policy (Bernanke, Gertler and Watson 1997; and Blanchard and Galí 2010); a more flexible labour market (Blanchard and Galí 2007); the changes in the oil intensity of economic activity; changes in the regulation of the energy market; changes in the composition of automobile production (Edelstein and Kilian 2009; Kilian 2009; and Ramey and Vine 2011); or a less elastic global demand curve over time (Baumeister and Peersman 2013).

For the specific case of Canada, several other factors can explain the time-varying nature of the relation. As stressed above, the Canadian economy switched from being a crude oil net importer to a net exporter. Indeed, since the beginning of the 1970s, the current account has fluctuated over time almost at the same amplitude as the price of crude oil (as we can see in Figure 1). Moreover, the structure of crude oil exports has changed recently (and will change in the near future) because economic and political considerations are leading Canada to consider ways to diversify its trading parterns, especially by expanding ties with

\footnotetext{
${ }^{29}$ One empirical exception is the oil price shock of the 1990s, which, according to Kilian and Murphy (2014), was mainly supply-driven.

${ }^{30}$ See Kilian 2009; Kilian and Park 2009; Peersman and Van Robays 2009; and Baumeister et al. 2010.

${ }^{31}$ The adequate proxies for these shocks are described in Appendix A.

${ }^{32}$ For cross-country evidence for this instability, see Baumeister et al. (2010).
} 
Asian emerging markets. Finally, a time-varying specification is in line with the well known intertemporal nature of the current account viewed as the outcome of forward-looking dynamic savings and investment decisions. ${ }^{33}$ Thus, in order to assess the evolution of the oil price passthrough to current account, and to distinguish between different sources of oil price shocks within a unified framework, we use the time-varying parameters vector autoregressive (TVPVAR) model with sign restriction, in line with Primiceri (2005), Cogley and Sargent (2005), and Baumeister and Peersman (2013).

The model is a multivariate structural VAR representation with both time-varying coefficients and a time-varying standard-error of innovation:

$$
B_{t} Y_{t}=d_{t}+C_{1, t} Y_{t-1}+\cdots+C_{p, t} Y_{t-p}+\Sigma_{t} v_{t}
$$

where $Y_{t}=\left[\Delta \ln \left(q_{t}\right), \Delta \ln \left(p_{o, t}\right), m i s_{t}, c a_{t}\right]^{\prime}$ is a vector of 4 endogenous variables. $q_{t}, p_{o, t}$, mist $_{t}$ and $c a_{t}$ denote, respectively, global oil production ${ }^{34}$, real oil prices, real exchange rate misalignments, and the ratio of current account to the gross domestic product. ${ }^{35}$ The variable $d_{t}$ is a vector of time-varying constants, $C_{i, t}(i=1, \ldots p)$ are matrix of time-varying lag coefficients of the structural model, and $v_{t}$ is a vector of structural innovations that is assumed to follow a multivariate normal distribution $v_{t} \rightsquigarrow \mathcal{N}\left(\mathbf{0}, \mathbf{I}_{4}\right)$.

The introduction of the global oil production permits controlling for unexpected changes in the world oil supply caused by exogenous events (such as those coming from the Middle East), and disentangling the demand and supply components of the oil shocks (see Rebucci and Spatafora 2006 and Baumeister and Peersman 2013). From a macroeconomic viewpoint, this is also in line with the literature dating back the 1970s about the dynamic effect of aggregate demand and supply disturbances on macroeconomic adjustments (see Sachs 1982; Blanchard and Quah 1989, to name a few). In addition, we introduce exchange rate misalignments as an indicator of competitiveness to capture the influence of undervaluation and overvaluation on current account. ${ }^{36}$ Figure 7 in the Appendix A suggests that the competitiveness channel could play an important role for Canada since it clearly shows that the phases of exchange rate overvaluation coincide with a deterioration of the current account, while the phases of exchange rate undervaluation are associated with an improvement in the current account.

We assume that the matrix of time-varying contemporaneous coefficients $B_{t}$ is lower triangular with ones along its diagonal, and that the matrix of standard-errors $\Sigma_{t}$ is diagonal. That is,

\footnotetext{
${ }^{33}$ One of the key insights of the intertemporal approach to the current account is that permanent shocks to the terms of trade have significantly different effects on the current account than transitory shocks.

${ }^{34}$ Note that since the share of Canadian oil production is about $5 \%$ of the total, a global oil production shock is not endogeneous to the production of the country.

${ }^{35}$ A detailed description of the data can be found in Appendix A.

${ }^{36}$ For more details on the estimation of the misalignments of Canada, refer to Appendix A.
} 


$$
B_{t}=\left(\begin{array}{cccc}
1 & 0 & 0 & 0 \\
b_{21, t} & 1 & 0 & 0 \\
b_{31, t} & b_{32, t} & 1 & 0 \\
b_{41, t} & b_{42, t} & b_{43, t} & 1
\end{array}\right) \text { and } \Sigma_{t}=\left(\begin{array}{cccc}
\sigma_{1, t} & 0 & 0 & 0 \\
0 & \sigma_{2, t} & 0 & 0 \\
0 & 0 & \sigma_{3, t} & 0 \\
0 & 0 & 0 & \sigma_{4, t}
\end{array}\right)
$$

Indeed, changes in the relations between the variables might come from changes in either the contemporaneous relations, the propagation mechanism, or the size of the shock that hits the model. Thus, letting the parameters of interest $B_{t}, C_{p, t}$ and $\sigma_{4, t}$ vary in time lets the data determine the nature of the changes that affect the relations between the variables in the model.

The reduced form representation of the structural model (1) is defined as

$$
Y_{t}=c_{t}+A_{1, t} Y_{t-1}+\cdots+A_{p, t} Y_{t-p}+\epsilon_{t}
$$

where $A_{i, t}=B_{t}^{-1} C_{i, t},(i=1, \ldots, p)$ are matrices of lag-coefficients, $c_{t}=B_{t}^{-1} d_{t}$ is a vector of constants, and $\epsilon_{t}=B_{t}^{-1} \Sigma_{t} v_{t}$ is the vector of reduced-form residuals. Following the structure of the contemporaneous coefficients matrix $B_{t}$ and that of the standard-errors of the structural innovations matrix $\Sigma_{t}$, we can assume that the reduced-form residuals follow a multivariate normal distribution $\epsilon_{t} \rightsquigarrow \mathcal{N}\left(\mathbf{0}, \Omega_{t}\right)$ where $\Omega_{t}$ is a symmetric and positive definite time-varying variance-covariance matrix that verifies the equality

$$
B_{t} \Omega_{t} B_{t}^{\prime}=\Sigma_{t} \Sigma_{t}^{\prime}
$$

The time paths for the parameters of interest are assumed to be random walks without drift. ${ }^{37}$ If we write $b_{t}=\left(b_{21, t} b_{31, t} b_{32, t} \cdots b_{43, t}\right)^{\prime}$ for the column vector that contains the elements of the matrix of contemporaneous relations $B_{t}, \alpha_{t}$ for the column vector that contains the stacked columns of the matrix $A_{t}=\left(c_{t} A_{1, t} \cdots A_{p, t}\right), \sigma_{t}=\left(\sigma_{1, t} \cdots \sigma_{4, t}\right)^{\prime}$ for the column vector that contains the diagonal elements of the matrix of standard errors $\Sigma_{t}$, and $h_{t}=\ln \left(\sigma_{t}\right)$ for the natural logarithm of the standard error, then the parameters evolve according to

$$
\begin{aligned}
\alpha_{t} & =\alpha_{t-1}+\omega_{t} \\
b_{t} & =b_{t-1}+\zeta_{t} \\
h_{t} & =h_{t-1}+\eta_{t}
\end{aligned}
$$

This specification has the principal advantage of modeling both possible abrupt breaks and gradual evolutions of the relations between the variables. Innovations in the reduced-form

\footnotetext{
${ }^{37}$ Even though the dynamics of the parameters can be easily extended to a more general autoregressive process, we assume a random walk process in order to capture possible permanent shifts.
} 
model are assumed to be jointly normally distributed:

$$
\left(\begin{array}{c}
v_{t} \\
\omega_{t} \\
\zeta_{t} \\
\eta_{t}
\end{array}\right) \rightsquigarrow \mathcal{N}(\mathbf{0}, V) \text { with } V=\left(\begin{array}{cccc}
\mathbf{I}_{4} & \mathbf{0} & \mathbf{0} & \mathbf{0} \\
\mathbf{0} & Q & \mathbf{0} & \mathbf{0} \\
\mathbf{0} & \mathbf{0} & S & \mathbf{0} \\
\mathbf{0} & \mathbf{0} & \mathbf{0} & W
\end{array}\right)
$$

where the matrix $S$ is assumed to be block diagonal. That is, we assume that the blocks corresponding to contemporaneous coefficients in each equation, are mutually independent. Each block of $S$ corresponds to the variance-covariance matrix of the contemporaneous coefficients of each equation in (1). ${ }^{38}$

\subsection{Identification scheme}

The structure of the variance-covariance matrix of the reduced-form residuals $\Omega_{t}$ in $(3)$ implies a Cholesky identification scheme restricting the matrix of contemporaneous relations to be lower triangular. In the literature of oil price studies, such as Kilian (2009), this is equivalent to an exclusion restriction. Hamilton (2003) uses a counterfactual experiment to identify oil supply shocks. In the present paper, we use a sign restriction to disentangle an oil supply shock from an oil demand shock. ${ }^{39}$

The sign-restriction approach adopted in this paper is the Householder transformations method developed by Fry and Pagan (2011), based on the QR decomposition of randomly selected square matrices from a normal distribution $\mathcal{N}(0, I(4)) .{ }^{40}$ As an identification scheme, we assume that after a negative oil production shock, world production decreases while oil prices increase. In turn, after a positive oil demand shock, world production is not affected, at least on impact (zero restriction), while the price of oil increases. Kilian (2009) found that an aggregate demand shock increases oil production with a delay of 6 months. This is because changes in oil production are costly and, thus, oil producers set their production on the basis of the expected growth trend rather than on the variation of world demand. As is widely accepted in the literature, we assume that an increase in demand for crude oil (precautionary or related to global activity) causes a somewhat sustained increase in the real price of oil that is substantial and persistent (the rise in oil prices holds for the four quarters following a

\footnotetext{
${ }^{38}$ Inferences of parameters of interest can be found in the Appendix B.

${ }^{39}$ In our model specification, we do not distinguish between the oil demand from global economic activity and that from the precautionary motive. This is to deal with the dimensionality problem arising from the number of parameters to be estimated.

${ }^{40}$ However, as argued by Fry and Pagan (2011), the difference between the Givens matrices (GM) method and the Householder transformations (HT) method is simply a matter of computational speed. These two methods are equivalent, but HT is more efficient than GM in terms of computational speed when the size of the VAR grows.
} 
demand shock). ${ }^{41}$ In contrast, a crude oil production disruption is assumed to cause a small and transitory increase in the real price of oil within the first year. In this context, we can expect that persistent shocks will affect curent account more significantly than do transitory ones. Finally, we assume that the exchange rate misalignments of Canada does not directly affect oil production and oil prices - a hypothesis which is realiste given the fact that the canadian dollar does not play a key role in the oil market (contrary to the USD).

\section{Results}

\subsection{The relation between current account and oil prices}

There is considerable evidence in the literature regarding the contemporaneous responses of the current account of oil-exporting countries following an oil price shock via a positive impact on the terms of trade (see Cashin et al. 2004; Chen and Chen 2007; to name a few). For the case of Canada, this fact is confirmed by Figure 4, where the oil price elasticity of current account has increased positively over time, due to the oil-trade balance surplus. This indicates that an oil price increase, whatever its origins, will trigger a current account surplus for Canada.

Moreover, the elasticity follows an upward trend with a value that is in general less than one. This indicates that the pass-through of oil price changes to the current account has increased over the considered period as the level of oil prices has risen, due to the high energy demand from emerging countries such as India and China and the limited oil supply capacity (see Rebucci and Spatafora 2006; and Stefanski 2014). It remains that the pass-through is incomplete over the period and that some additional adjustment mechanisms are needed to mitigate the effect of the oil price shocks on the current account. The adjustments at work in the current account go through the non-oil trade balance adjustment. The more the country runs a non-oil trade balance deficit after an oil price increase, the more the initial oil-trade balance surplus is offset. This effect is materialized by the low value of the oil price elasticity of the current account in Figure 4. The adjustment proportion depends on several external and internal factors. First, as an external aspect, the strength of the oil price movements and the origins of the shocks are of course the most important factors in our context, especially because we now know that not all oil shocks are alike. Second, as internal aspects, the propensity to spend oil-extra revenues on imports, the ability to manage exchange rate reserves, economic policy, the degree of openness, and the degree of international financial market integration, are the main factors. In the next section, we look at the effect of the

\footnotetext{
${ }^{41}$ After a precautionary demand shock, the price of oil responds immediately while an aggregate demand disturbance causes somewhat delayed oil price movements (Kilian 2009). Note that our approach does not distinguish between the two demands but rather includes both of them.
} 
Figure 4: Contemporaneous relation between CA and oil prices.

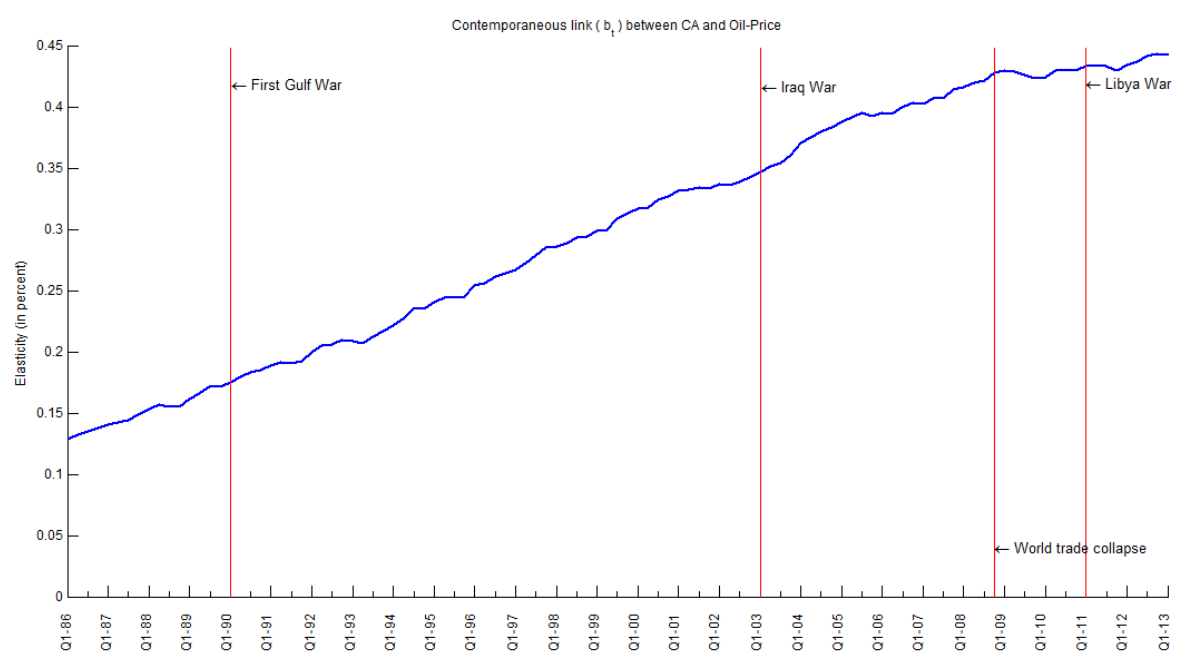

price of oil on current account by disentangling supply and demand shocks, and then we provide a formal assessment of the role of each factor in the adjustment of the trade balance.

\subsection{Impulse response function}

We assess in this section the responses of the current account to unexpected increases in oil prices, of different natures (such as supply and demand shocks). It is worth mentioning that the size of the innovation in our analysis is time-varying. As a consequence, the magnitude of the impulse responses depends on the size of the shock hitting the model each period. Therefore, the standard approach of depicting the responses of the variables following a given shock with a size of one standard deviation is not appropriate in the context of time-varying parameters. In order to make the impulse responses comparable across periods, a normalization is required. We assume that for each period, a negative oil supply shock generates a decrease in global oil production of $1 \%$ while a positive demand shock leads to an increase in the price of oil of 10\%. In addition, as argued by Baumeister and Peersman (2013), the feedback effet of the macreconomic variables following an oil price shock occurs with a delay of one year. Therefore, the following impulse response functions are the four-quarter cumulative impulse responses of the current account after an oil supply and oil demand shock.

Figure 5 depicts the impulse response function of the Canadian current account following an 
Figure 5: IRF of the current account following an oil supply shock.

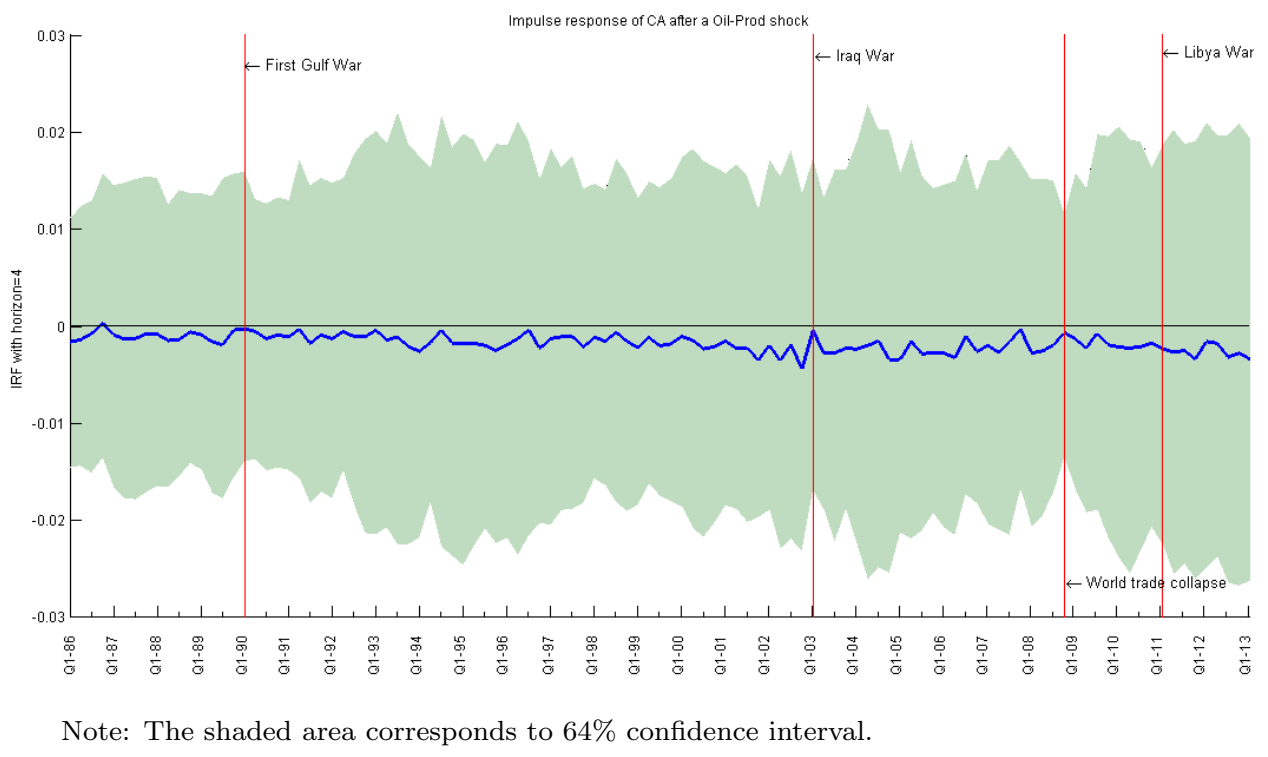

oil production shortfall.

It appears that a world oil production shortfall generates a non-significant negative impact on the current account of Canada over the considered period. Two reflexions can emerge from this observation: (i) most of the oil price shocks from the 1980s were demand-driven, and so the price of oil was too; thus we have a negligible impact of the oil supply shock on current account; and (ii) supply shocks have, by definition, transitory effects on oil price movements, and so the response of the current account following the shock can only be short-lived. Since 1974, the empirical literature has provided overwhelming evidence that oil prices have been driven by global demand shocks (see Alquist and Kilian 2010 among other). One exception is the 1990s, where flow supply shocks played an important role (see Kilian and Murphy 2014). However, even during that period, the effect of an unexpected flow supply disruption remains minor, leaving further discussion needed regarding the demand channel.

Figure 6 reports the impulse response function of the current account following an oil demand shock. It indicates that oil demand shocks have a delayed but significant and persistent positive impact on current account. The results also reveal that the contribution of an oil demand shock to current account is different, depending on the oil price intensity. For instance, the period that just followed the invasion of Kuwait in 1990, the Afghan War in 2001, and the Iraq War in 2002-03, are episodes characterized by sharp spikes in oil prices and are also those that have led to important current account fluctuations. This result is even more 
Figure 6: IRF of the current account following an oil demand shock.

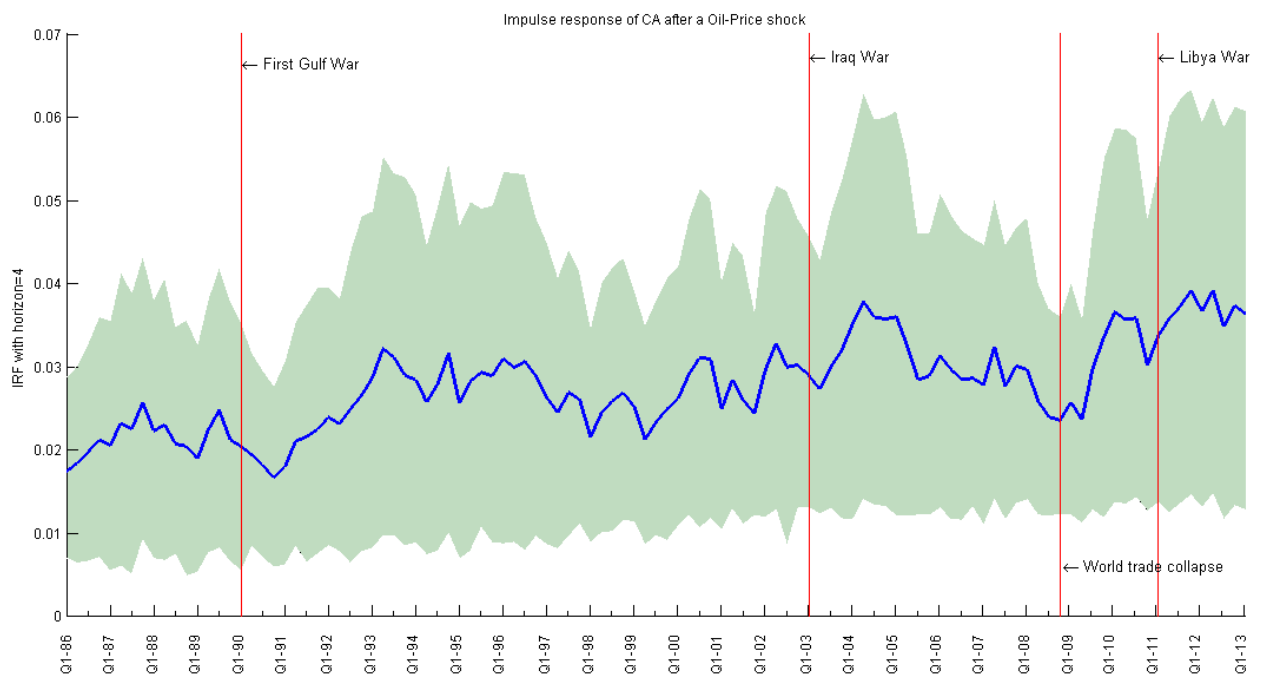

Note: The shaded area corresponds to $64 \%$ confidence interval.

relevant for the episodes of 1990 and of 2002-2003, where the empirical literature has found evidence of surges in speculative demand for oil (see Kilian 2009; and Kilian and Murphy 2014). The 1999 OPEC meeting is, in contrast, associated with small price movements and a rather parsimonious response of the current account. The most interesting episode in the oil market over the last decades is obviously the unprecedented price flucutation during the 2007-2009 recession. According to a popular view, this price increase was the consequence of speculative behavior on the market, the so-called financialization of oil futures markets, and could not be explained by changes in fundamentals (see Fattouh et al. 2013 for an interesting discussion). However, whatever the origin of the demand (i.e. precautionary or linked to the business cycle), this particular episode has led to important fluctuations in the current account of Canada.

\subsection{The role of adjustment factors}

As shown in Figure 6, the magnitude of the oil demand shock pass-through into current account has increased over time during the considered period. However, the pass-through remains incomplete, indicating that adjustment factors are at work in the non-oil trade balance. For instance, following a positive oil price shock on current account, the non-oil trade balance should vary in the opposite direction than the initial oil-trade surplus. The same 
reasoning applies when oil prices decrease. In order to look at which adjustment factors (i.e. the propensity to spend oil-extra revenues on imports, the ability to manage exchange rate reserves, economic policy, the degree of openness, and the degree of international financial market integration) deal with the initial effect of the oil price fluctuations on the current account, we ran two robust OLS regressions that capture the propensity of each factor to affect the oil demand shock pass-through into current account. Equation (a) regresses the oil demand shock pass-through into current account on a set of adjustment factors, such as the propensity to spend oil revenues on imports (MP), the logarithm of foreign exchange reserves (LRES), and the degree of domestic financial market development (DEPH). In order to examine how monetary policy could influence the pass-through, Equation (b) replaces LRES by the ratio of the foreign exchange reserves to the money supply (RES_M2). An increase in this ratio can be interpreted as an attempt to sterilize foreign exchange inflows to avoid overvaluation. By nature, the relation between RES_M2 and the oil demand shock pass-through should be positive in the case of sterilization. ${ }^{42}$

Table 2: Oil price demand shock

\begin{tabular}{|c|c|c|c|c|}
\hline & \multicolumn{2}{|c|}{ (a) } & \multicolumn{2}{|c|}{ (b) } \\
\hline & Coefficient & z-Statistic & Coefficient & $z$-Statistic \\
\hline MP & $-0.92^{* *}$ & -2.33 & $-0.91^{* *}$ & -2.12 \\
\hline DEPH & $0.20^{* * *}$ & 2.90 & $0.33^{* * *}$ & 7.63 \\
\hline LRES & $0.35^{* * *}$ & 2.95 & & \\
\hline RES_M2 & & & $0.06^{*}$ & 1.65 \\
\hline Constant & -3.28 & -1.16 & $3.91^{* *}$ & 2.44 \\
\hline Observation & & & & \\
\hline R-squared & & & & \\
\hline
\end{tabular}

Note: Robust Least Squares are used for estimations. ${ }^{* * *}\left(\right.$ resp. $\left.{ }^{* *},{ }^{*}\right)$ : significant at the $1 \%$

(resp. 5\%, 10\%) level.

Table 2 presents the estimation results of Equations (a) and (b) and shows that the propensity to spend oil revenues on imports (MP) has a significant negative influence on the oil demand shock pass-through (in line with Rebucci and Spatafora, 2006; Kilian et al., 2009). However, as we have seen, the pass-through has continuously increased over time, leaving some space for other tools that Canada could use to adjust the current account. More formally, we find that both the degree of domestic financial market development (DEPH) and the management of foreign exchange reserves (LRES) have a positive and significant impact on the pass-through.

\footnotetext{
${ }^{42}$ More details on the macroeconomic data are provided in the Appendix A.
} 
First, the degree of domestic financial market development reflects the mechanism behind the accounting identity that links the current account to net savings investment. Deeper financial market development allows a higher propensity to save for intergenerational equity arguments, precautionary motives, and consumption smoothing considerations. Second, the monetary authority may accumulate foreign exchange reserves following an oil revenue windfall in order to relieve appreciation pressure on the real effective exchange rate. This permits containing a domestic price increase that would hurt the competitiveness of exporting firms and raise imports. The management of foreign exchange reserves allows controling the non-oil trade balance deficit, and thus obtaining a higher final impact of an oil price increase on the current account. The results of Equation (b) show that the sign and significance of the different explanatory factors remain valid once we control for a possible sterilization policy using the ratio of the foreign exchange reserves to M2 (RES_M2).

\subsection{Policy implications}

As stated previously, oil price surges have been advanced in the literature as the main cause of the recent observed global imbalances. The link between oil prices and current account thus plays an important role both in academic and policy debates, in particular for oil exporting countries. Indeed, as a natural resource, oil reserves are intended to be depleted. Moreover, it is well known that oil prices are characterized by strong volatility and that an oil windfall is temporary by its very nature. In the literature on the management of oil revenues, this savings-investment trade-off has led to a constellation of studies, for which Berg et al. (2013) provides a comprehensive and recent review. In line with this ongoing issue, it is worthwhile to derive some policy implications from the findings of this study. On the one hand, previous results have shown the important role played by the domestic import-competitive firms in the link between current account and oil prices. If oil revenues are spent on imports, the positive effect of an oil price increase on current account will be mitigated. To a certain extent, this finding highlights the beneficient impact of diversification on oil exporting countries, which is well documented in the literature. On the other hand, our results show that in the context of a diversified economy, as is the case of Canada, the degree of domestic financial development and the management of foreign exchange reserves are positively correlated with the nexus between oil prices and the current account. The former permits a higher propensity to save. Even for developing oil resource-rich countries with higher spending and investment needs, saving a part of the oil revenues is necessary for precautionary motives given the volatility of oil prices and to sustain the capital built during an oil windfall, as argued by Berg et al. (2013). In turn, an active monetary policy is necessary to contain real exchange rate appreciation pressure. This permits shielding non-oil export firms and domestic import-competitive firms from a loss of competitiveness. 


\section{Conclusion}

This study has revisited the nexus between current account and oil prices. This is an important issue raised by the global imbalances that have followed the recent oil price surge. More importantly, this is still an ongoing issue. For oil-importing countries, it allows measuring the extent of the negative impact of an oil price increase on the economy, and knowing the different, possibly automatic, adjustment mechanisms that permit cushioning this adverse effect. For oil-exporting countries, this issue is closely linked to the good management of oil revenue windfalls for intergenerational equity concerns and to the phenomenon of the 'resource curse' that might affect resource-rich countries. The particular characteristics of Canada make the country-case study in this paper more appealing. Namely, it is classified among the largest oil-exporters but has a sufficiently diversified export structure.

Indeed, there is a large body of theoretical and empirical studies that treat directly or indirectly this issue, of which we have provided a recent review. What we have learned from this literature is that a positive oil price surge will generate a current account surplus for oilexporting countries at the expense of oil-importing countries. The magnitude of the relation, however, will depend on various adjustment factors that are country-specific, which make this subject an outstanding issue. Using an innovative method that permits capturing the timevarying nature of the relation between current account and oil prices, and also distinguishing between different sources of oil price innovations, we have found the following results.

First, for the whole sample period, we estimated a positive relation between current account and the price of oil. This finding supports the well-documented evidence that an increase in the price of oil generates a current account surplus for oil exporting countries. Second, an oil supply shock has a short-lived and non-significant impact on the current account. Third, an oil physical or precautionary demand shock has a delayed but sustained significant positive impact on current account, which in addition has increased over time. Fourth, the initial oil-trade balance surplus that follows an unexpected demand-driven oil price increase might be partially transmitted to current account. Mainly, we have found that the propensity to spend oil revenues on imports has a significant negative influence on the oil demand shock pass-through to current account, while the degree of domestic financial market development and the management of foreign exchange reserves have a significant inverse effect. 


\section{References}

[1] Aizenman, J., Sun, Y., 2010. Globalization and the sustainability of large current account imbalances: size matters. Journal of Macroeconomics 32, 35-44.

[2] Allegret, J.-P., Couharde, C., Coulibaly, D., Mignon, V., 2013. Current accounts and oil price fluctuations in oil-exporting countries: the role of financial development. Journal of International Money and Finance 47, 185-201.

[3] Alquist, R., Guénette, J.D., 2014. A blessing in disguise: The implications of high global oil prices for the North American market. Energy Policy 64, 49-57.

[4] Alquist, R., Kilian, L., 2010. What Do We Learn from the Price of Crude Oil Futures? Journal of Applied Econometrics 25, 539-573.

[5] Alquist, R., Kilian L., Vigfusson R., 2013. Forecasting the Price of Oil. in Graham Elliot and Allan Timmerman, eds., Handbook of Economic Forecasting 2 (Dordrecht: NorthHolland, 2013).

[6] Arezki, R., Hasanov, F., 2013. Global imbalances and petrodollars. World Economy 36, 213-232.

[7] Backus, D., Crucini, M., 2000. Oil Prices and the Terms of Trade. Journal of International Economics 50, 185-213.

[8] Barsky, R. B., Kilian, L., 2002. Do We Really Know that Oil Caused the Great Stagflation? A Monetary Alternative. in B. Bernanke and K. Rogoff (eds.), NBER Macroeconomics Annual 2001, 137-183.

[9] Barsky, R. B., Kilian, L., 2004. Oil and the Macroeconomy since the 1970s. Journal of Economic Perspectives 18, 115-134.

[10] Basher, S. A., Fachin, S., 2013. The long-run relationship between savings and investment in oil-exporting developing countries: A case study of the Gulf Arab states, OPEC Economy Review 37, 429-446.

[11] Baumeister, C., Peersman, G., Van Robays, I., 2010. The economic consequences of oil shocks: differences across countries and time. In R. Fry, C. Jones, and C. Kent, editors, Inflation in an Era of Relative Price ShocksÂ, RBA Annual Conference Volume. Reserve Bank of Australia (June 2010).

[12] Baumeister, C., Peersman, G., 2013. Time-varying effects of oil supply shocks on the US economy.American Economic Journal: Macroeconomics 5, 1-28. 
[13] Bems, R., de Carvalho Filho, I., 2011. The current account and precautionary savings for exporters of exhaustible resources. Journal of International Economics 84, 48-64.

[14] Berg, A., Portillo, R., Yang, S. C. S., Zanna, L. F., 2013. Public investment in resourceabundant developing countries. IMF Economic Review 61, 92-129.

[15] Bernanke, B. S., Gertler, M., Watson, M., Sims, C. A., Friedman, B. M., 1997. Systematic monetary policy and the effects of oil price shocks. Brookings papers on economic activity 1997, 91-157.

[16] Bernanke, B. S., 2006. Energy and the economy. Speech 221, Board of Governors of the Federal Reserve System (U.S.).

[17] Blanchard, O., Quah, D., 1989. The Dynamic Effects of Aggregate Demand and Supply Disturbances. American Economic Review 79, 655-673.

[18] Blanchard, O., Galí, J., 2007. Real Wage Rigidities and the New Keynesian Model. Journal of Money, Credit, and Banking 39, 35-65.

[19] Blanchard, O., Galí, J., 2010. International dimensions of monetary policy. In J. Gali and M. J. Gertler, editors, The Macroeconomic Effects of Oil Price Shocks: Why are the 2000s so different from the 1970s? pp. 373-421. University of Chicago Press.

[20] Blanchard, O., Milesi-Ferretti, G. M., 2010. Global Imbalances: In Midstream, in: Reconstructing the World Economy, edited by Il SaKong and Olivier Blanchard, Washington DC: International Monetary Fund.

[21] Bodart, V., Candelon, B., Carpantier, J.-F., 2012. Real exchanges rates in commodity producing countries: a reappraisal. Journal of International Money and Finance 31, 1482-502.

[22] Bodart, V., Candelon, B., Carpantier, J. F., 2015. Real exchanges rates, commodity prices and structural factors in developing countries. Journal of International Money and Finance 51, 264-284.

[23] Bodenstein, M., Erceg, C. J., Guerrieri, L., 2011. Oil shocks and external adjustment. Journal of International Economics 83, 168-184.

[24] Bollino, C. A., 2007. Oil prices and the U.S. trade deficit. Journal of Policy Modeling 29, 729-738.

[25] Bruno, M., Sachs, J., 1982. Energy and resource allocation: a dynamic model of the "Dutch Disease". Review of Economic Studies 49, 845-859.

[26] Buetzer, S., Habib, M. M., Stracca L., 2012. Global exchange rate configurations: Do oil shocks matter? European Central Bank Working Paper No. 1442. 
[27] Burbidge, J., Harrison, A., 1984. Testing for the effects of oil-price rises using vector autoregressions. International Economic Review 25, 459-484.

[28] Cadot, O., Carrère, C., Strauss-Kahn, V., 2011. Export Diversification: What's behind the Hump? Review of Economics and Statistics 93, 590-605.

[29] Carter, C. K., Kohn, R. (1994). On Gibbs sampling for state space models. Biometrika $81,541-553$.

[30] Cashin, P., Céspedes, L. F., Sahay, R., 2004. Commodity currencies and the real exchange rate. Journal of Development Economics 75, 239-268.

[31] Chen, S. S., Chen, H. C., 2007. Oil prices and real exchange rates. Energy Economics 29, 390-404.

[32] Chen, Y. C., Rogoff, K., 2003. Commodity currencies. Journal of international Economics 60, 133-160.

[33] Cherif, R., Hasanov, F., 2013. Oil exporters' dilemma: How much to save and how much to invest. World Development 52, 120-131.

[34] Chinn, M. D., Ito, H., 2007. Current account balances, financial development and institutions: Assaying the world "saving glut". Journal of international money and Finance 26, 546-569.

[35] Christopoulos, D., León-Ledesma, M. A., 2010. Current account sustainability in the US: What did we really know about it? Journal of International Money and Finance 29, 442-459.

[36] Cogley, T., Sargent, T. J., 2005. Drifts and volatilities: monetary policies and outcomes in the post WWII US. Review of Economic dynamics 8, 262-302.

[37] Corden, W. M., Neary, J. P., 1982. Booming sector and de-industrialisation in a small open economy. Economic journal 92, 825-848.

[38] Coudert, V., Couharde, C., Mignon, V., 2011. Does euro or dollar pegging impact the real exchange rate? The case of oil and commodity currencies. World Economy 34, 1557-1592.

[39] Devereux, M. B., Sutherland, A., 2010. Valuation effects and the dynamics of net external assets. Journal of international Economics 80, 129-143.

[40] Edelstein, P., Kilian, L., 2009. How sensitive are consumer expenditures to retail energy prices? Journal of Monetary Economics 56, 766-779.

[41] Edwards, S., 2005. Is the U.S. Current Account Deficit Sustainable? And if not, How Costly Is Adjustment Likely to be? NBER Working Paper No. 11541 (August). 
[42] Fattouh, B., Kilian, L., Mahadeva, L., 2013. The role of speculation in oil markets: what have we learned so far? Energy Journal 34, 7-34.

[43] Frankel, J. A., 2010. The Natural Resource Curse: A Survey, NBER Working Paper No. 15836. Cambridge, MA: National Bureau of Economic Research.

[44] Freund, C., 2005. Current account adjustment in industrial countries. Journal of International Money and Finance 24, 1278-1298.

[45] Fry, R., Pagan, A., 2011. Sign restrictions in structural vector autoregressions: A critical review. Journal of Economic Literature 49, 938-960.

[46] Gavin, M., 1990. Structural adjustment to a terms of trade disturbance: the role of relative prices. Journal of International Economics 28, 217-243.

[47] Gavin, M., 1992. Monetary policy, exchange rates, and investment in a Keynesian economy. Journal of International Money and Finance 11, 145-161.

[48] Ghironi, F., Lee, J., Rebucci, A., 2015. The valuation channel of external adjustment. Journal of International Money and Finance 57, 86-114.

[49] Gisser, M., Goodwin, T.H., 1986. Crude oil and the macroeconomy: Tests of some popular notions. Journal of Money, Credit, and Banking 18, 95-103.

[50] Gourinchas, P. O., Rey, H., 2007a. From world banker to world venture capitalist: US external adjustment and the exorbitant privilege. In G7 Current Account Imbalances: Sustainability and Adjustment (pp. 11-66). University of Chicago Press.

[51] Gourinchas, P. O., Rey, H., 2007b. International Financial Adjustment. Journal of Political Economy 115, 665-703.

[52] Hamilton, J.D., 1983. Oil and the macroeconomy since World War II. Journal of Political Economy 91, 228-248.

[53] Hamilton, J. D., 2003. What is an oil shock?. Journal of Econometrics 113, 363-398.

[54] Hamilton, J. D., 2009. Understanding Crude Oil Prices. Energy Journal 30, 179-206.

[55] Herrera, A. M., Pesavento, E., 2009. Oil price shocks, systematic monetary policy, and the "Great Moderation". Macroeconomic Dynamics 13, 107-137.

[56] Hooker, M. A., 1996. What happened to the oil price-macroeconomy relationship? Journal of monetary Economics, 38(2), 195-213.

[57] Kilian, L., 2008. Exogenous oil supply shocks: how big are they and how much do they matter for the US economy? Review of Economics and Statistics 90, 216-240. 
[58] Kilian, L., 2009. Not All Oil Price Shocks Are Alike: Disentangling Demand and Supply Shocks in the Crude Oil Market. American Economic Review 99, 1053-1069.

[59] Kilian, L., Murphy, D. P., 2014. The role of inventories and speculative trading in the global market for crude oil. Journal of Applied Econometrics 29, 454-478.

[60] Kilian, L., Park, C., 2009. The impact of oil price shocks on the US stock market. International Economic Review 50, 1267-1287.

[61] Kilian, L., Rebucci, A., Spatafora, N., 2009. Oil shocks and external balances. Journal of international Economics 77, 181-194.

[62] Kilian, L., Vega, C., 2011. Do energy prices respond to US macroeconomic news? A test of the hypothesis of predetermined energy prices. Review of Economics and Statistics 93, 660-671.

[63] Kim, I. M., Loungani, P., 1992. The role of energy in real business cycle models. Journal of Monetary Economics 29, 173-189.

[64] Kim, S., Shephard, N., Chib, S., 1998. Stochastic volatility: likelihood inference and comparison with ARCH models. Review of Economic Studies 65, 361-393.

[65] Lane, P. R., Milesi-Ferretti, G. M., 2007. A global perspective on external positions. In G7 current account imbalances: sustainability and adjustment (pp. 67-102). University of Chicago Press.

[66] Lane, P. R., Milesi-Ferretti, G. M., 2012. External adjustment and the global crisis. Journal of International Economics 88, 252-265.

[67] Le, T. H., Chang, Y., 2013. Oil price shocks and trade imbalances. Energy Economics $36,78-96$.

[68] Lee, K., Ni, S., 2002. On the dynamic effects of oil price shocks: a study using industry level data. Journal of Monetary economics 49, 823-852.

[69] Morsy, H., 2012. Current account determinants for oil-exporting countries. Emerging Markets Finance and Trade 48, 122-133.

[70] Neary, P., 1988. Determinants of the equilibrium real exchange rate. American Economic Review 78, 210-215.

[71] Ostry, J. D., Reinhart, C. M., 1992. Private saving and terms of trade shocks: Evidence from developing countries.Staff Papers 39, 495-517.

[72] Özlale, Ü., Pekkurnaz, D. (2010). Oil prices and current account: A structural analysis for the Turkish economy. Energy Policy 38, 4489-4496. 
[73] Peersman, G., Van Robays, I. (2009). Oil and the Euro area economy. Economic Policy 24, 603-651.

[74] Primiceri, G. E., 2005. Time varying structural vector autoregressions and monetary policy. Review of Economic Studies 72, 821-852.

[75] Ramey, V. A., Vine, D. J., 2011. Oil, Automobiles, and the US Economy: How Much Have Things Really Changed? In NBER Macroeconomics Annual 2010, Vol. 25 (pp. 333-367). University of Chicago Press.

[76] Rebucci, A., Spatafora, N., 2006. Oil prices and global imbalances. IMF World Economic Outlook 4, 71-96.

[77] Sachs J. 1982. The Current Account in the Macroeconomic Adjustment Process. Scandinavian Journal of Economics 84, 147-59.

[78] Schoder, C., Proaño, C. R., Semmler, W., 2013. Are The Current Account Imbalances Between Emu Countries Sustainable? Evidence From Parametric And NonParametric Tests. Journal of Applied Econometrics 28, 1179-1204.

[79] Stefanski, R., 2014. Structural transformation and the oil price. Review of Economic Dynamics 17, 484-504.

[80] Van der Ploeg, R., Venables, A. J., 2012. Natural Resource Wealth: The Challenge of Managing a Windfall. Annual Review of Economics 4, 315-337. 


\section{A Data appendix}

In this section, we present a detailed description of the data used in the paper. The sample period of our database is quarterly and covers the 49 years from 1964Q1 to 2013Q1. All data are extracted from the Datastream and Macrobond databases.

The measure of fluctuations in global economic activity is proxied by the dry cargo shipping index developed by Kilian (2009). The global crude oil production comes from the Energy Information Agency (EIA). The speculative component of the oil demand relies on the data for U.S. crude oil inventories provided by the EIA.

- $q_{t}$ : the series of global oil production is from the BP Statistic Review of World Energy (from Macrobond). The series starts from 1973Q1. We therefore use an interpolated version of the annual series 'WD Oil Production - World VOLN' from Datastream (code: WDOPPOI) to approximate its values before 1973Q1.

- $p_{o, t}$ : the series of nominal oil prices is the 'WD Commodity Prices: Crude Oil nadj $(2005=100)$ ' from Datastream (code: WDQ76AADF). It is the average of the U.K. Brent, Dubai, and West Texas Intermediate, end of period prices in USD. This series is deflated by the United States consumer price index to obtain the real price of oil used in the estimation.

- The CPI index used as deflator is the 'United States, IMF IFS, Interest Rates, Prices, Production \& Labor, Consumer Prices, CPI All Items City Average, 2005=100' from Macrobond.

- The real effective exchange rate (REER) comes from the database of the Bank for International Settlements (BIS), narrow indices covering 27 economies, with data from $1964(100=2010)$. The real effective exchange rate is defined as the weighted average of the bilateral exchange rates adjusted by the relative consumer prices.

- $n f a_{t}$ : the series of net foreign assets (as a percentage of GDP) used in the estimation of the misalignments. The NFA are from the IMF database on International Financial Statistics (IFS) and are provided by Macrobond.

- $\operatorname{prod}_{t}$ : the series of relative productivity. Prod is the level of GDP per capita PPPadjusted measured relative to a weighted-average of GDP per capita PPP-adjusted of Canada's trading partners (the same as those used in the REER calculation).

- $c a_{t}$ : the series of the ratio of current account to gross domestic product is the 'OECD MEI, BOP Current Account as a Percentage of GDP, SA' from Macrobond. This series starts only from 1990Q1. To obtain previous values, we backcast the series using 
Table 3: Unit root test and Cointegration test

\begin{tabular}{|c|c|c|c|}
\hline & \multicolumn{3}{|c|}{ ADF Unit root test (a) } \\
\hline & Level & First difference & \\
\hline Variables & $t$-Statistic & $t$-Statistic & Conclusion \\
\hline lreer & -1.49 & -9.91 & $\mathrm{I}(1)$ \\
\hline$n f a$ & -1.53 & -15.05 & $\mathrm{I}(1)$ \\
\hline \multirow[t]{3}{*}{ lprod } & -0.80 & -15.52 & $\mathrm{I}(1)$ \\
\hline & \multicolumn{3}{|c|}{ "Engle and Granger cointegration test (b) } \\
\hline & $\mid t-$ Statistic $\mid$ & $\begin{array}{c}\text { Engle and Yoo } \\
\text { critical value at } 5 \%\end{array}$ & \\
\hline residues & 4.30 & 3.78 & $\mathrm{I}(0)$ \\
\hline
\end{tabular}

Notes: (a) The results show that the three series are integrated of order 1. KPSS tests also confirm these results. (b) The results also confirm the existence of a cointegrating relation between the real effective exchange rate and its long-term fundamentals.

the 'Current Account Balance, as a Percentage of GDP, OECD Economic Outlook, Estimate, Calendar Adjusted, SA' from Macrobond.

- $m i s_{t}$ : the series of exchange rate misalignments. Roughly speaking, exchange rate misalignments are defined as the difference between the observed real effective exchange rate and its estimated equilibrium level. The latter is derived from the estimation of a cointegrating relation between the real effective exchange rate (reer) and its two usual determinants, namely the net foreign asset position $(n f a)$ and a proxy for relative productivity $(\operatorname{prod})$. This approach is based on a simple stock-flow model, following Alberola et al. (1999) and Bénassy-Quéré et al. (2009, 2010) among others. The estimation of the misalignments is given by

$$
\text { mis }_{t}=\text { reer }_{t}-\widehat{\text { lreer }}_{t}=\text { lreer }_{t}-1.23 n f a-2.16 \text { lprod }
$$

The equilibrium exchange rate $\left(\widehat{\operatorname{lreer}}_{t}\right)$ is estimated by the Dynamic OLS (DOLS) method and the $t$-statistics are in parentheses. prod and reer are taken in logarithms while $n f a$ is a percentage of GDP. Before estimating the long-term relation between the real effective exchange rate and its fundamentals, preliminary tests for unit roots and cointegration have been made. Their results are shown in the tables below:

- $M P$ : A measure of the propensity to spend oil revenues on imports. This is the ratio 
Figure 7: Exchange rate misalignments and current account in Canada

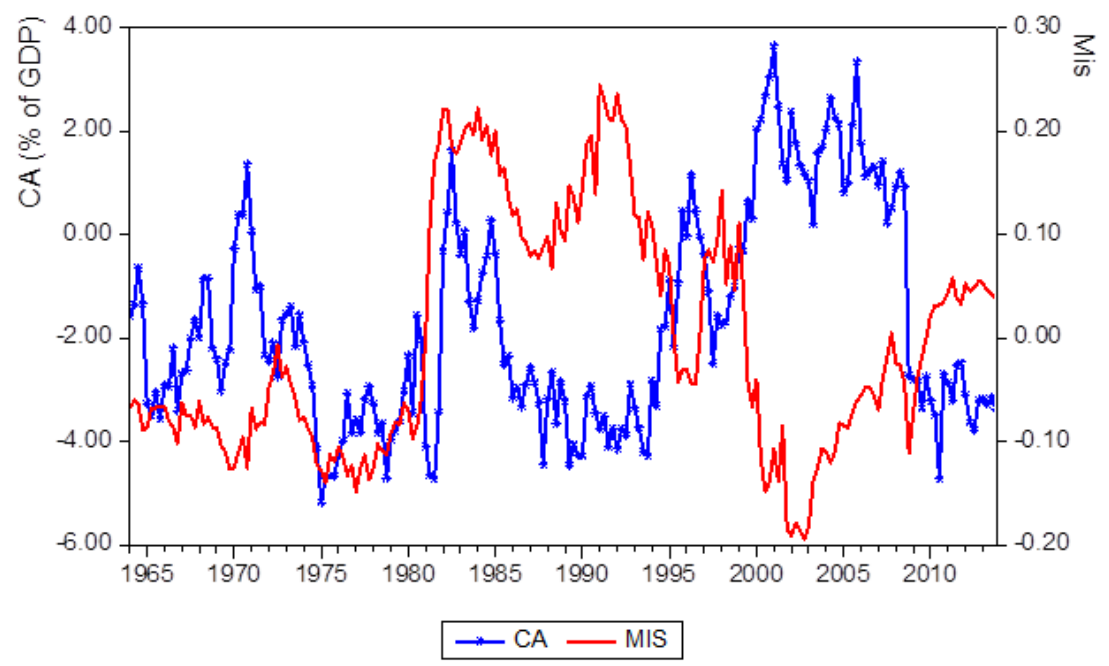

between import expenditure (at constant prices) and oil export revenues (at constant prices). Data come from Statistics Canada.

- DEPH: A measure of the degree of domestic financial market development. This is the ratio of the amount of credit extended by domestic banks to the private sector to the GDP. The data on loans extended come from the Bank for International Settlements (BIS) and are obtained from Macrobond.

- LRES: Logarithm of official international reserves. The data are from International Financial Statistics (IFS) of the IMF.

\section{B Bayesian inference}

As in Cogley and Sargent (2005), the parameters of interest $A_{t}, B_{t}$ and $\Sigma_{t}$, are expressed in a state space representation. Using the reduced form equation (2), the law of motion of the parameters (4) and the normality assumption of the innovations $v_{t}$ and $w_{t}$, the lag coefficients $A_{t}$ have a linear Gaussian state-space representation. In turn, the lower triangularity, diagonality, and bloc diagonality assumptions for $B_{t}, \Sigma_{t}$ and $S$, respectively, ensure a linear Gaussian state space representation of contemporaneous coefficients. Therefore, the joint posterior density for $A_{t}$ and $B_{t}$ is a product of independent normal distributions. However, the standard error coefficients $\Sigma_{t}$ can be transformed into a linear state-space representation which is no 
longer Gaussian. Instead, they are distributed as $\ln \left(\chi^{2}(1)\right)$. As in Kim et al. (1998), the $\ln \left(\chi^{2}(1)\right)$ distribution can be approximated by a mixture of 7 normal distributions.

The entire sequence of parameters of interest, $A_{t}, B_{t}$ and $\Sigma_{t}$, is generated via forward and backward recursion of a Kalman filter using a Gibbs sampler. Namely, the estimates of the parameters are obtained using the Carter and Kohn (1994) simulation smoother.

\section{B.1 The priors}

The specifications of the prior distribution in this paper follow Primiceri (2005). The initial values for the time-varying parameters and variance-covariance matrices are assumed to be mutually independent. An initial training sample of 80 observations was used to generate OLS point estimates of the parameters of interest. The priors of the initial values of the reduced form VAR parameters $A_{0}$, the contemporaneous coefficients $B_{0}$ and the logarithm of volatilities $\ln \Sigma_{0}$ are assumed to follow a normal distribution with mean equal to the corresponding OLS estimates of the parameter, and a variance equal to four times the corresponding OLS variance for $A_{0}$ and $B_{0}$, and equal to the identity matrix for $\ln \Sigma_{0}$. That is,

$$
\begin{aligned}
\alpha_{0} & \rightsquigarrow \mathcal{N}\left(\hat{\alpha}_{\text {ols }}, 4 \cdot V\left(\hat{\alpha}_{\text {ols }}\right)\right) \\
b_{0} & \rightsquigarrow \mathcal{N}\left(\hat{b}_{\text {ols }}, 4 \cdot V\left(\hat{b}_{\text {ols }}\right)\right) \\
h_{0} & \rightsquigarrow \mathcal{N}\left(\hat{h}_{\text {ols }}, \mathbf{I}_{4}\right)
\end{aligned}
$$

The priors of the different blocks of the variance-covariance matrix $V$ are, in turn, assumed to be independent and to follow an inverted Wishart distribution. That is,

$$
\begin{aligned}
Q & \rightsquigarrow \mathcal{I W}\left(k_{Q}^{2} \cdot 80 \cdot V\left(\hat{b}_{\text {ols }}\right), 80\right) \\
S_{[i]} & \rightsquigarrow \mathcal{I} \mathcal{W}\left(k_{S}^{2} \cdot(i+1) \cdot V\left(\hat{b}_{\text {ols }}\right),(i+1)\right) \\
W & \rightsquigarrow \mathcal{I} \mathcal{W}\left(k_{W}^{2} \cdot(5) \cdot \mathbf{I}_{n},(5)\right)
\end{aligned}
$$

where $k_{Q}^{2}=0.01, k_{S}^{2}=0.1, k_{W}^{2}=0.01, n$ is the number of endogenous variables in the system and $S_{[i]}$ corresponds to the $i^{t h}$ block of the matrix $S$. Note that these assumptions as to the priors, together with the random walk assumption in (4), imply normal priors on the entire sequences of $A_{t}, B_{t}$ and $\Sigma_{t}$ conditional on $Q, S$ and $W$. Set this way, the priors are not flat but sufficiently diffuse and uninformative to let the data determine the best estimates of the parameters. 


\section{B.2 The posterior distribution}

Given that the state-space models of the parameters of interest are linear and Gaussian, the posterior distributions of the state variables $\alpha_{t}\left|Y_{t}, B_{t}, \Sigma_{t}, Q, b_{t}\right| Y_{t}, \alpha_{t}, \Sigma_{t}, S$ and $h_{t} \mid Y_{t}, \alpha_{t}, B_{t}, W$ are generated using forward and backward recursion with a Kalman filter. The variancecovariance matrices $Q, S$ and $W$ are generated from their respective independent posterior distributions, which are assumed to follow an inverted Wishart distribution. That is,

$$
\begin{aligned}
Q \mid Y_{t}, A_{t}, B_{t}, \Sigma_{t} & \rightsquigarrow \mathcal{I} \mathcal{W}\left(\left(\sum_{t=p+1}^{T} \omega_{t} \omega_{t}^{\prime}+\underline{Q}\right),(T-p+\underline{q})\right) \\
S_{[i]} \mid Y_{t}, A_{t}, B_{t}, \Sigma_{t} & \rightsquigarrow \mathcal{I} \mathcal{W}\left(\left(\sum_{t=p+1}^{T} \zeta_{[i] t} \zeta_{[i] t}^{\prime}+\underline{S_{[i]}}\right),\left(T-p+\underline{s_{[i]}}\right)\right) \\
W \mid Y_{t}, A_{t}, B_{t}, \Sigma_{t} & \rightsquigarrow \mathcal{I} \mathcal{W}\left(\left(\sum_{t=p+1}^{T} \eta_{t} \eta_{t}^{\prime}+\underline{W}\right),(T-p+\underline{w})\right)
\end{aligned}
$$

where $\underline{Q}, S_{[i]}$ and $\underline{W}$ are positive definite scale matrices from the inverted Wishart prior distributions of $Q$, the block matrix $S_{[i]}$ of $S$ and $W$, and $\underline{q}, s_{[i]}, \underline{w}$ are their degrees of freedom, respectively.

\section{B.3 Markov Chain Monte Carlo (MCMC) algorithm}

To summarize, the Markov Chain Monte Carlo (MCMC) algorithm takes the following form:

1. Specify the initial sequence of $A_{t}, B_{t}, \Sigma_{t}, D_{t}$ and $V$.

2. Generate the states $\alpha_{t}$ conditional on $Y_{t}, B_{t}, \Sigma_{t}$ and $Q$ using Kalman filter for $t=$ $1, \ldots, T$.

3. Generate off-diagonal elements $b_{t}$ of the contemporaneous matrix $B_{t}$ conditional on $Y_{t}$, $\alpha_{t}, \Sigma_{t}$ and $S$ using Kalman filter for $t=1, \ldots, T$.

4. Generate volatilities $\sigma_{t}$ conditional on $Y_{t}, \alpha_{t}, b_{t}, D_{t}$ and $W$ using Kalman filter for $t=1, \ldots, T$.

5. Generate a new selection matrix $D_{t}$ by sampling from $P\left(d_{i t}=k \mid Y_{i t}^{* *}, h_{i t}\right)$ conditional on $Y_{t}, \alpha_{t}, b_{t}, \sigma_{t}$ for $t=1, \ldots, T$. 
6. Generate the variance-covariance matrix $V$ by sampling from an independent inverted Wishart distribution.

7. Check for stationarity of the VAR, and if, and only if, it is stationary, store the parameters of interest.

8. Go to step 2.

It is worth noting that step 7 is implemented in order to ensure that the realizations of the VAR are stationary and that only stationary draws are accepted and stored. 